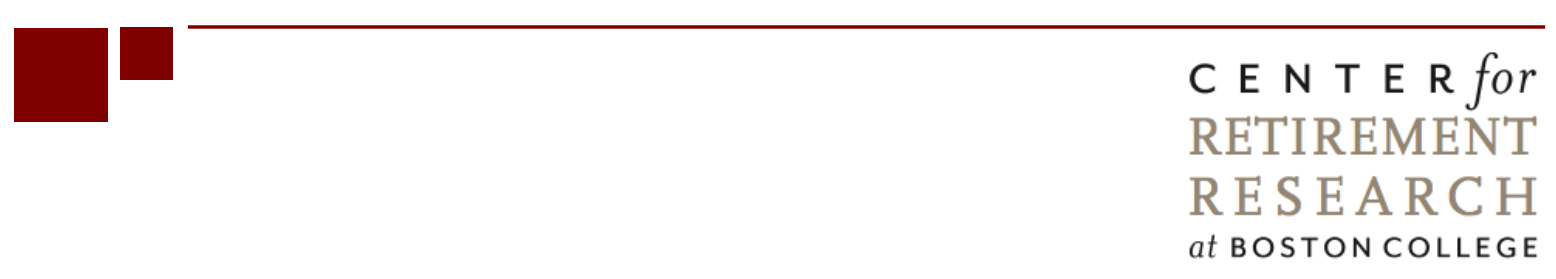

\title{
SSI FOR DISABLED IMMIGRANTS: WHY DO ETHNIC NETWORKS MATTER?
}

Delia Furtado and Nikolaous Theodoropoulos

CRR WP 2013-7

Submitted: February 2013

Released: February 2013

\author{
Center for Retirement Research at Boston College \\ Hovey House \\ 140 Commonwealth Avenue \\ Chestnut Hill, MA 02467 \\ Tel: 617-552-1762 Fax: 617-552-0191 \\ http://crr.bc.edu
}

Delia Furtado is an associate professor in the department of economics at the University of Connecticut. Nikolaos Theodoropoulos is a lecturer in the department of economics at the University of Cyprus. The research reported herein was pursuant to a grant from the U.S. Social Security Administration (SSA) funded as part of the Retirement Research Consortium (RRC). The findings and conclusions expressed are solely those of the authors and do not represent the views of SSA, any agency of the federal government, the RRC, the University of Connecticut, the University of Cyprus, or Boston College. The authors would like to thank Louis Christofides, Shelly Lundberg, and Steven Stern for many helpful comments and Patricia Barnes for preparing the restricted data file at the Research Data Center (RDC).

(C) 2013, by Delia Furtado and Nikolaos Theodoropoulos. All rights reserved. Short sections of text, not to exceed two paragraphs, may be quoted without explicit permission provided that full credit, including (C) notice, is given to the source. 


\begin{abstract}
About the Steven H. Sandell Grant Program
This paper received funding from the Steven H. Sandell Grant Program for Junior Scholars in Retirement Research. Established in 1999, the Sandell program's purpose is to promote research on retirement issues by scholars in a wide variety of disciplines, including actuarial science, demography, economics, finance, gerontology, political science, psychology, public administration, public policy, sociology, social work, and statistics. The program is funded through a grant from the Social Security Administration (SSA). For more information on the Sandell program, please visit our website at: http://crr.bc.edu/about-us/grant-programs/stevenhsandell-grant-program-2/ send e-mail to crr@bc.edu, or call Marina Tsiknis at (617) 552-1092.
\end{abstract}

\title{
About the Center for Retirement Research
}

The Center for Retirement Research at Boston College, part of a consortium that includes parallel centers at the University of Michigan and the National Bureau of Economic Research, was established in 1998 through a grant from the Social Security Administration. The Center's mission is to produce first-class research and forge a strong link between the academic community and decision-makers in the public and private sectors around an issue of critical importance to the nation's future. To achieve this mission, the Center sponsors a wide variety of research projects, transmits new findings to a broad audience, trains new scholars, and broadens access to valuable data sources.

\author{
Center for Retirement Research at Boston College \\ Hovey House \\ 140 Commonwealth Avenue \\ Chestnut Hill, MA 02467 \\ phone: 617-552-1762 fax: 617-552-0191 \\ e-mail: crr@bc.edu \\ crr.bc.edu
}

Affiliated Institutions:

The Brookings Institution

Massachusetts Institute of Technology

Syracuse University

Urban Institute 


\begin{abstract}
Immigrants residing among many co-ethnics are especially likely to receive Supplemental Security Income (SSI) for a disability when they belong to high SSI take-up immigrant groups. After showing that this relationship cannot be fully explained by differences in health, we consider the likely sources of these network effects by separately examining their role in the decision to apply for SSI and, conditional on applying, their role in determining who ultimately receives benefits. Our results suggest that networks may increase the probability of applying for SSI despite minor disabilities, but it is unlikely that network effects are driven by egregious lies on applications.
\end{abstract}




\section{Introduction}

The Supplemental Security Income (SSI) program provides cash benefits to the elderly, blind, and disabled with low incomes and limited assets. As is the case with any transfer program, two natural concerns arise with respect to SSI. First, are all eligible people receiving the benefits to which they are entitled? Second, are otherwise ineligible people manipulating the system in order to receive benefits? The first may be of particular concern for the foreign-born given that the application process can present a formidable barrier for people with limited knowledge of English and U.S. programs. The second may be of particular concern to immigration policymakers if they believe that immigrants come to the U.S. explicitly to receive these benefits. This paper sheds light on these two issues by examining the role of ethnic networks in determining SSI take-up among working-age immigrants.

If disability and poverty were exogenously determined and SSI funds perfectly allocated, then we would not expect to find any evidence that exposure to people receiving SSI would increase the probability of take-up. Furtado and Theodoropoulos (2012) find, even when controlling for country of origin and area of residence fixed effects, that immigrants residing among many co-ethnics are especially likely to receive SSI when they belong to high SSI takeup ethnic groups. We make two contributions to this work. First, we explore whether this relationship can be fully explained by differences in health behaviors and health status. Next, we consider the likely sources of network effects by separately examining the role of networks in explaining the decision to apply for SSI and, conditional on applying, their role in determining who ultimately receives benefits.

\section{Background}

Like Social Security Disability Insurance (SSDI), the largest disability program in the United States, SSI is run by the Social Security Administration and provides cash benefits to the blind and disabled of working age. In contrast to SSDI, the SSI program does not have work history requirements but is instead targeted to people with limited incomes and assets. Minimum cash benefits are established at the federal level, but states often supplement these funds.

The SSI and SSDI programs use the same process to determine who is disabled. After local offices establish whether applicants satisfy the non-disability-related requirements of either

of the two programs, applications, consisting of detailed medical reports, are sent to Disability 
Determination Services (DDS) offices. These state-run but federally-funded offices determine whether applicants have disabilities which not only prevent them from working but are expected to last at least a year or result in death. Of all SSI applications submitted in 2002 by working-age individuals who satisfied the non-medical conditions for approval, a little over half were eventually awarded benefits based on medical criteria (SSI Annual Statistical Report 2011).

Applicants who are denied benefits can typically ask for reconsideration by a second team of examiners at the same DDS office. If they are again rejected, they can appeal to an Administrative Law Judge, then to the Social Security Appeals Council, and then to district courts. The appeals process can take years and may involve lengthy legal battles, but success rates are high. About half of the 18 to 64-year-old 2002 applicants who were initially denied appealed the decision and more than 56 percent of those who appealed were eventually awarded benefits (SSI Annual Statistical Report 2011). ${ }^{1}$

Before 1996, generally all immigrants legally in the U.S. were eligible for SSI, but the 1996 Personal Responsibility and Work Opportunity Reconciliation Act along with the Illegal Immigration Reform and Immigrant Responsibility Act limited access to all non-citizens, including legal permanent residents. Immigrants who were legally in the U.S. before 1996 retained access to the SSI safety net in the event of a disability. Non-citizens who entered the country post-enactment may qualify for benefits if they are refugees, have sufficient work histories in the U.S., or participated in the military, but in general, are not eligible for SSI.

\section{III.Do Ethnic Networks affect SSI Take-Up among Disabled Immigrants?}

It is difficult to identify causal relationships between networks and the take-up of social assistance programs. Positive correlations between exposure to people receiving benefits and take-up of a program might be explained by unobserved characteristics, common to people in the same social circle, which affect eligibility (see Manski 1993). For example, people living in certain cities may have high SSI take-up rates because they are applying for benefits at the same, potentially more lenient, DDS office. Similarly, high take-up rates among immigrants from certain countries might be explained by their shared refugee status or lack of work experience.

Starting with the work on welfare cultures by Bertrand, Luttmer and Mullainathan (2000), these issues have typically been addressed by examining whether take-up among

\footnotetext{
${ }^{1}$ We use the number people who applied for reconsideration as our measure of initial appeals. Because ten states do not have a reconsideration stage (appeals go straight to the courts), we underestimate the total number of appeals.
} 
immigrants residing among many co-ethnics is especially high when they belong to high take-up ethnic groups. This strategy allows researchers to control for country of origin fixed effects, area of residence fixed effects, as well as the share of the population in a person's area of residence that shares the person's ethnic background. This general approach has been used to uncover network effects in the take-up of welfare (Aslund and Fredriksson 2009), Medicaid (Gee and Giuntella 2011), prenatal care assistance (Aizer and Currie 2004), and Special Supplemental Nutrition Program for Women, Infants and Children (Figlio, Hammersma, and Roth 2011).

While our ultimate goal is to more carefully examine the mechanisms through which ethnic networks affect SSI take-up, we start by replicating the Furtado and Theodoropoulos (2012) Census-based findings using data from the National Health Interview Survey (NHIS), a data set with significantly fewer immigrants than the U.S. Census but with detailed information on health. The NHIS also asks whether people applied for SSI benefits, regardless of whether they ultimately receive them. To maximize sample size, we pool surveys from 1997 to 2011. Our baseline sample consists of 143,620 immigrants aged 25 to 64 who do not have missing data on the dependent variable, baseline control variables and country of origin. Immigrants from Puerto Rico and other U.S. territories were dropped from the sample.

Following Furtado and Theodoropoulos (2012), we estimate the following equation,

$$
S S I_{i j k}=\beta_{1} C A_{j k} \times \overline{S S I}_{j}+\beta_{2} C A_{j k}+\mathbf{X}_{i \mathrm{ikk}} \boldsymbol{\beta}^{\prime}{ }_{3}+\gamma_{j}+\delta_{k}+e_{i j k},
$$

where SSI equals one if person $i$ from country $j$ living in area $k$ is receiving SSI for a disability and zero otherwise. Contact availability, CA, is the log of the proportion of people living in area $k$ that belong to ethnic group $j$ while $\overline{S S I}$ is the proportion of immigrants in the U.S. from country j receiving SSI disability benefits. Controls for age and age squared, gender, educational attainment, marital status, having a child in the home, and year of the survey are included in the vector $\mathbf{X}$. Country of origin fixed effects, $\gamma_{j}$, and areas of residence fixed effects, $\delta_{k}$, are used in all specifications. Our measure of network effects, $\beta_{1}$, is expected to be positive if immigrants living in areas with many co-ethnics are more likely to receive SSI when they belong to ethnic groups with high SSI take-up rates.

Using the restricted version of the NHIS accessed at the Research Data Center, we have access to data on respondents' county of residence in the U.S. as well as their country of birth. However, the significantly smaller sample size of the NHIS makes it impossible to construct 
accurate measures of CA even when pooling multiple years of data. Thus, we obtain data on the proportion of each county's population from each country of origin from the 2000 U.S. Census Summary File 3. The summary files are aggregate-level data constructed using data on all "long form” Census respondents, a fifteen percent sample of the U.S. population. We merged the contact availability variable constructed using Census Summary Files with the NHIS individual data by country of origin and county of residence.

Approximately 1 percent of the immigrants in our sample receive SSI for a disability. ${ }^{2}$ Take-up varies quite substantially across ethnic groups ranging from 8.0 among Iraqis to zero among Swedes. Some of this variation can easily be accounted for by differences in the age and educational distributions across ethnic groups. To formally account for these differences, we turn to regression analysis.

Column 1 of Table 1 shows regression results for our baseline specification. Consistent with Furtado and Theodoropoulos (2012), immigrants living in counties with large co-ethnic populations are especially likely to receive SSI when they belong to ethnic groups with high SSI take-up rates. ${ }^{3}$ The magnitude of the coefficient is smaller than what was found using Census microdata, but we suspect this is because the more recent NHIS surveys include more immigrants who do not qualify for SSI given the 1996 reforms.

\section{IV.Health Behaviors and Outcomes}

The first major contribution of our paper is to consider whether these patterns can be explained by differences in health. Immigrants in high take-up groups may be more likely to smoke, have poor diets, or lack exercise. If these patterns are exacerbated when they reside amidst many co-ethnics, then our estimated network effects may reflect the role of peers in determining health behaviors as opposed sharing information or establishing norms specifically about SSI.

\footnotetext{
${ }^{2}$ According to the Social Security Administration, 2.6 percent of the U.S. resident population received SSI benefits in 2011 (Table 13; SSI Annual Statistical Report, 2011). SSI take-up is lower in our sample both because many immigrants are not eligible for SSI and because the NHIS does not sample people in institutions, many of whom receive SSI.

${ }^{3}$ While it is true that a positive estimated interaction coefficient might be explained by occupational similarities within social circles, Furtado and Theodoropoulos (2012) showed that baseline results were robust to controlling for the likelihood of being injured on the job and unemployment rates within country of origin and area of residence cells.
} 
Information on health behaviors is only available for a limited sample, known as the adult sample, within the NHIS. Column 2 of Table 1 shows results for the baseline model using the adult sample. The network effect is estimated to be stronger in this sample. In column 3, controls for smoking (a dummy variable equal to one if the person is currently a smoker and zero otherwise) and body mass index (BMI) are added. As expected given the relationships between these variables and many potentially disabling diseases such as diabetes, heart disease, and cancer, smokers and people with higher BMIs are more likely to receive SSI. However, adding these variables has very little impact on our estimated network coefficient suggesting that health behaviors are not driving the baseline SSI results.

Admittedly, there is a host of other health behaviors, potentially correlated within ethnic groups especially for people residing among many co-ethnics, which may determine ultimate impairment. Simple genetics might also explain disability patterns. Because these health characteristics are difficult to measure, we add a catch-all measure of health to the model. The NHIS asks respondents to evaluate their current health on the following scale: "Poor, Fair, Good, Very Good, and Excellent”. Results from a model including dummy variables for these responses (excellent health is the omitted category) are shown in Column 4 of Table 1. People who self-report having worse health are more likely to receive SSI benefits, but again, the inclusion of these variables decreases the estimated network coefficient only slightly. We conclude, therefore, that while differences in health can explain part of our estimated interaction coefficient, a significant and quantitatively important SSI network effect remains.

\section{Mechanisms}

In this section, we explore the mechanisms through which ethnic networks operate by separately examining the decision to apply for SSI and, conditional on applying, the likelihood of receiving benefits. Ethnic networks may impact the probability of applying for benefits for many reasons. People who know others receiving benefits would know the program exists and could very easily gather information on the application process, the income and asset constraints, and the severity of disability needed to obtain benefits. Norms may also play a role in determining who applies for benefits. Taboos enforced within social circles might explain why some severely disabled individuals might undergo financial hardship but still refuse to apply for government assistance. It is also possible that, in social groups with little stigma attached to 
receiving SSI, people with minor disabilities apply hoping to being matched with a lenient DDS examiner. Maestas, Mullen, and Strand (2011) find that 23 percent of SSDI applicants are at the margin of acceptance in that whether they receive benefits depends on the examiner to whom they were initially assigned.

In contrast to the variety of ways networks may increase the likelihood of applying for SSI, the mechanisms through which ethnic networks can impact the probability of an ultimately successful application, among those who apply, are much more specific. Networks may be useful for distributing information on which doctors are likely to provide compelling evidence that a person is disabled and which lawyers have the best record of winning SSI appeals. More lax taboos against exaggerating disabilities may also increase the likelihood that applications are successful if DDS examiners and appeals judges cannot perfectly assess the accuracy of medical claims.

It is also possible that people with more exposure to SSI recipients have a lower probability of receiving benefits, conditional on applying, than those with less exposure. If people know about the program, they receive help in filling out applications, and there is very little stigma against receiving SSI, then they may apply for benefits despite having only minor disabilities. If these marginal applications are ultimately rejected, then we might see that immigrants surrounded by co-ethnics are less likely to receive SSI, conditional on applying, if they belong to high SSI ethnic groups.

Table 2 shows regression results of the two models. In column 1, the dependent variable equals one if the person ever applied for SSI benefits and zero otherwise. Just as in the baseline models, immigrants with more exposure to co-ethnics with high rates of take-up are more likely to apply for benefits. In fact, our results suggest that ethnic networks have a stronger impact on the decision to apply for benefits than on receiving benefits. Column 2 of Table 2 shows results from a model restricted to a sample of immigrants who have in the past applied for SSI benefits. The dependent variable equals one if the person is receiving SSI and zero otherwise. In this model, the estimated network coefficient takes on a negative value. While this result is inconsistent with networks operating through information sharing on filling out successful applications and hiring the best lawyers, it is consistent with people applying for benefits despite having only marginal disabilities when they have more exposure to co-ethnics on SSI. The 
estimated interaction coefficient is only statistically significant at the 10 percent level, but we note that sample size drops quite dramatically in this model.

\section{Conclusion}

This paper investigates the role of ethnic networks in determining SSI take-up among disabled working-age immigrants. Using NHIS data, we replicate the findings in the literature that immigrants living among many co-ethnics are especially likely to take-up SSI if they belong to a high SSI take-up ethnic group. We then show that these relationships are robust to controlling for several health behaviors and a self-reported measure of overall health. Finally, we show that networks seem to positively affect the decision to apply but have a negative impact on the likelihood of receiving benefits conditional on applying. This suggests that people learn about the SSI program within ethnic communities and perhaps form norms about the appropriateness of applying despite having only minor disabilities. It does not, however, seem likely that network effects are driven by norms promoting egregious lies on applications or shared information about the best lawyers to navigate the appeals process. 


\section{References}

Aizer, Anna, and Janet Currie. 2004. "Networks or Neighborhoods? Correlations in the Use of Publicly-Funded Maternity Care in California.” Journal of Public Economics, 88(12): 2573585.

Aslund, Olof, and Peter Fredriksson. 2009. "Peer Effects in Welfare Dependence: QuasiExperimental Evidence.” Journal of Human Resources, 44(3): 798-825.

Bertrand, Marianne, Erzo F. P. Luttmer, and Sendhil Mullainathan. 2000. "Network Effects and Welfare Cultures.” Quarterly Journal of Economics, 115(3), 1019-055.

Figlio, David N., Sarah Hamersma, and Jeffrey Roth. 2011. "Information Shocks and Social Networks.” Working Paper 16930. Cambridge, MA: National Bureau of Economic Research

Furtado, Delia, and Nikolaos Theodoropoulos. 2012. "Immigrant Networks and the Take-up of Disability Programs: Evidence from U.S. Census Data.” Working Paper 2012-23. Chestnut Hill, MA: Center for Retirement Research at Boston College.

Gee, Emily R., and G. Osea Giuntella. 2011. "Medicaid and Ethnic Networks.” The B.E. Journal of Economic Analysis \& Policy, 11(1) (Contributions): Article 77.

Maestas, Nicole, Kathleen Mullen, and Alexander Strand. 2011. “Does Disability Insurance Receipt Discourage Work? Using Examiner Assignment to Estimate Causal Effects of SSDI Receipt.” Working Paper Series 853-2. Santa Monica, CA: RAND Corporation.

Manski, Charles F. 1993. "Identification of Endogenous Social Effects: The Reflection Problem.” Review of Economic Studies, 60(3): 531-42.

National Center for Health Statistics. National Health Interview Survey, 1997-2011. SSI Annual Statistical Report. 2011. SSA Publication No. 13-11827. http://www.ssa.gov/policy/docs/statcomps/ssi_asr/index.html (accessed November 20, 2012).

U.S. Bureau of the Census. Census 2000 Summary File 3 [machine-readable data files]. Washington, DC: US Bureau of the Census, 2002 (accessed January 29, 2012). 
Table 1. The Effect of Ethnic Networks on SSI Receipt

\begin{tabular}{|c|c|c|c|c|}
\hline Dependent variable: SSI & $(1)$ & (2) & (3) & (4) \\
\hline \multirow[t]{2}{*}{ CA * Proportion of co-ethnics receiving SSI } & $0.152^{* * *}$ & $0.238 * * *$ & $0.219 * * *$ & $0.143^{* * *}$ \\
\hline & $(0.031)$ & $(0.055)$ & $(0.050)$ & $(0.029)$ \\
\hline CA & $\begin{array}{c}-0.001^{* * *} \\
(0.000)\end{array}$ & $\begin{array}{c}-0.001 * * \\
(0.001)\end{array}$ & $\begin{array}{c}-0.001 * * \\
(0.001)\end{array}$ & $\begin{array}{c}-0.001^{* * *} \\
(0.000)\end{array}$ \\
\hline BMI & --- & -- & $\begin{array}{c}0.001^{* * *} * \\
(0.000)\end{array}$ & --- \\
\hline Current smoker & --- & --- & $\begin{array}{c}0.004^{* *} \\
(0.002)\end{array}$ & --- \\
\hline Very good health & --- & --- & & $\begin{array}{c}-0.0003 \\
(0.000)\end{array}$ \\
\hline Good health & --- & --- & & $\begin{array}{c}0.004^{* * *} * \\
(0.001)\end{array}$ \\
\hline Fair health & --- & --- & & $\begin{array}{c}0.039 * * * \\
(0.003)\end{array}$ \\
\hline Poor health & --- & --- & & $\begin{array}{c}0.147 * * * \\
(0.009)\end{array}$ \\
\hline Observations & 143,620 & 55,919 & 53,264 & 143,553 \\
\hline Adjusted R-squared & 0.033 & 0.046 & 0.045 & 0.078 \\
\hline \multicolumn{5}{|c|}{$\begin{array}{l}\text { Notes: Linear probability models are used throughout. Columns } 1 \text { and } 4 \text { use the person sample of the NHIS while columns } 2 \text { and } \\
3 \text { use the adult sample. Controls for age, age squared, gender, educational attainment, marital status, having a child at home, year } \\
\text { of the survey, and county and country fixed effects are included in all models. Standard errors, clustered by county and county of } \\
\text { origin, are in parentheses. Observations are weighted using NHIS-provided person weights in columns } 1 \text { and } 4 \text { and adult weights } \\
\text { in columns } 2 \text { and } 3 \text {. Significance levels are noted by the following: *** significance at } 1 \% \text {, }{ }^{* *} \text { significance at } 5 \% \text {, * significance } \\
\text { at } 10 \% \text {. }\end{array}$} \\
\hline
\end{tabular}

Table 2. Mechanisms Through Which Ethnic Networks Operate

\begin{tabular}{lcc}
\hline \hline & Ever Applied for SSI & SSI \\
& $(1)$ & $-1.265^{*}$ \\
CA * Proportion of co-ethnics receiving SSI & $0.212^{* * *}$ & $(0.708)$ \\
& $(0.037)$ & $0.025^{*}$ \\
CA & $-0.001 * *$ & $(0.015)$ \\
\hline Observations & $(0.000)$ & 2,721 \\
Adjusted R-squared & 143,479 & 0.305 \\
\hline Notes: Column 1 uses the full sample while column 2 is restricted to a sample of SSI applicants. Controls for age, age squared, \\
gender, educational attainment, marital status, having a child at home, year of the survey, and county and country fixed effects \\
are included in all models. Standard errors, clustered by county and county of origin, are in parentheses. Observations are \\
weighted using the NHIS-provided person weights. Significance levels are noted by the following: *** significance at $1 \%,{ }^{* *}$ \\
significance at 5\%, * significance at 10\%.
\end{tabular}




\section{RECENT WORKING PAPERS FROM THE CENTER FOR RETIREMENT RESEARCH AT BOSTON COLLEGE}

The Use of VA Disability Benefits and Social Security Disability Insurance Among Veterans

Janet M. Wilmoth, Andrew S. London, and Colleen M. Heflin, February 2013

How Does the Composition of Disability Insurance Applicants Change Across Business Cycles?

Norma B. Coe and Matthew S. Rutledge, February 2013

The Economic Implications of the Department of Labor's 2010 Proposals for BrokerDealers

Alicia H. Munnell, Anthony Webb, and Francis M. Vitagliano, January 2013

What Is the Long-Term Impact of Zebley on Adult and Child Outcomes?

Norma B. Coe and Matthew S. Rutledge, January 2013

Sticky Ages: Why Is Age 65 Still a Retirement Peak?

Norma B. Coe, Mashfiqur Khan, and Matthew S. Rutledge, January 2013

Rethinking Optimal Wealth Accumulation and Decumulation Strategies in the Wake of the Financial Crisis

Richard W. Kopcke, Anthony Webb, and Josh Hurwitz, January 2013

Employee Mobility and Employer-Provided Retirement Plans

Gopi Shah Goda, Damon Jones, and Colleen Flaherty Manchester, November 2012

Changing Sources of Income Among the Aged Population

Barry P. Bosworth and Kathleen Burke, November 2012

Holding Out or Opting Out? Deciding Between Retirement and Disability Applications in Recessions

Matthew S. Rutledge, November 2012

Automatic Enrollment, Employee Compensation, and Retirement Security

Barbara A. Butrica and Nadia S. Karamcheva, November 2012

401(k) Participant Behavior in a Volatile Economy

Barbara A. Butrica and Karen E. Smith, November 2012

All working papers are available on the Center for Retirement Research website (http://crr.bc.edu) and can be requested by e-mail (crr@bc.edu) or phone (617-552-1762). 